\title{
Natural dye as light-harvesting pigments for quasi-solid-state dye-sensitized solar cells
}

\author{
Negese Yazie $^{1} \cdot$ Delele Worku $^{1,2,3} \cdot$ Abebe Reda $^{2,3}$
}

Received: 8 October 2015/ Accepted: 12 July 2016/Published online: 25 July 2016

(c) The Author(s) 2016. This article is published with open access at Springerlink.com

\begin{abstract}
In this paper, quasi-solid-state dye-sensitized solar cell has been constructed based on natural photosensitizers extracted from the bracts of Bougainvillea spectabilis and the leaves of Euphorbia cotinifolia using acidified $(0.1 \mathrm{M} \mathrm{HCl})$ distilled water and ethanol separately. The absorption spectra of the extracts were performed in the spectral range from 395 to $750 \mathrm{~nm}$. The cells were assembled using commercial $\mathrm{TiO}_{2}$ powder film and PEDOT coated FTO glasses as working and counter electrodes, respectively, and also the quasi-solid electrolyte sandwiched in between. The Photovoltaic parameters such as short circuit current density $\left(J_{\mathrm{sc}}\right)$, open circuit voltage $\left(V_{\mathrm{oc}}\right)$, fill factor $(\mathrm{FF})$, and overall conversion efficiency $(\eta)$ for the as-prepared DSSC were determined under $100 \mathrm{~mW} /$ $\mathrm{cm}^{2}$ illuminations. The highest open circuit voltage $\left(V_{\mathrm{oc}}=0.549 \mathrm{~V}\right)$ and short circuit current density $\left(J_{\mathrm{sc}}=0.592 \mathrm{~mA} / \mathrm{cm}^{2}\right)$ were obtained from the DSSCs assembled by natural dye extracted with the acidified ethanol of Bougainvillea spectabilis bracts and the leaves of Euphorbia cotinifolia, respectively. The highest power conversation efficiency $(\eta)$ of the as-prepared DSSC assembled with natural dye extracted from Bougainvillea spectabilis bracts using acidified ethanol as extracting solvent was $0.175 \%$. The use of Bougainvillea spectabilis
\end{abstract}

Delele Worku

delelew@bdu.edu.et; delelewww@yahoo.com

1 Material Science and Engineering Program, College of Science, Bahir Dar University, P.O. Box 79, Bahir Dar, Ethiopia

2 Department of Chemistry, Bahir Dar University, P.O. Box 79, Bahir Dar, Ethiopia

3 Energy Research Center, Bahir Dar University, P.O. Box 79, Bahir Dar, Ethiopia and Euphorbia cotinifolia pigments as natural sensitizers along with the use of quasi-solid electrolyte and PEDOT coated FTO counter electrodes could be a possible alternative for the production of low-cost and environment friendly DSSCs.

Keywords Dye-sensitized solar cell - Titanium dioxide . Natural dyes · Quasi-solid state electrolyte · Counter electrode

\section{Introduction}

Currently, the solar cells available commercially are based on inorganic silicon semiconductors, made of p-n junctions, which are relatively expensive to manufacture and also the manufacturing process releases harmful emissions to the environment that cause pollution. Hence, hybrid solar cells appear to be highly promising and cost-effective alternatives for photovoltaic energy sectors due to its relatively cheapness to produce, and promising efficiency. In this regard, dye sensitized solar cells (DSSCs) have been given considerable attention in recent years [1]. DSSC, which was invented by Michael Grätzel and Brian O'Regan in 1991, is a device that converts visible light energy into electrical energy based on the sensitization of the wide band gap semiconductors $[2,3]$ by suitable regenerative dyes. A DSSC consists of a porous wide band gap semiconductor thin film layer like $\left(\mathrm{TiO}_{2}, \mathrm{ZnO}, \mathrm{SnO} 2, \mathrm{Nb}_{2} \mathrm{O}_{5}\right)$ coated on a fluorine-doped tin oxide (FTO) or indiumdoped tin oxide (ITO) photoanode electrode, a dye, a platinum $(\mathrm{Pt})$ or carbon or conductive polymer thin film counter electrode and an electrolyte normally containing $\mathrm{I}^{-} / \mathrm{I}_{3}{ }^{-}$redox couple. Titanium dioxide $\left(\mathrm{TiO}_{2}\right)$ is most commonly used as photoanode in DSSC application since 
it is nontoxic, inert, and has a large energy bandgap as well as good optical and electrical properties and, thus, can be efficiently sensitized by a dye [4]. In DSSC, the dye plays an important role in harvesting solar energy and converting it to electrical energy with the aid of a semiconducting photoanode. Therefore, the cell performance is mainly dependent on the type of dye used as a sensitizer in which the absorption spectrum and the anchorage of the dye to the surface of $\mathrm{TiO}_{2}$ are important parameters in determining the efficiency of the cell $[5,6]$. Several metal complexes and organic dyes have been synthesized and used as sensitizers. Among these, ruthenium based complexes are considered as the most efficient sensitizers because of their intense charge -transfer absorption over the entire visible range and highly efficient metal-to-ligand charge transfer $[2,3,7]$. However, these advantages are offset by their rarity, high cost, complicated synthetic routes, and environmental threat. Thus, an alternative organic dye such as natural dyes is suggested with similar characteristic with an acceptable efficiency [8-10]. Recently, research has focused on the easily available dyes extracted from natural sources because of their large absorption coefficients, high light-harvesting efficiency, complete biodegradation, low cost, simple and safe preparation and eco-friendly. Thus far, several dyes such as anthocyanins, carotenoids, betalains and chlorophylls extracted from parts of different plants (such as Jathropha curcas, Citrus aurantium, red cabbage and etc.) have been used as sensitizers in DSSC $[11,12]$.
In this paper, we have extracted natural dyes from the bracts of a shrub Bougainvillea spectabilis and the leaves of Euphorbia cotinifolia and studied their potential application to be employed as sensitizers for DSSC manufacturing using $\mathrm{TiO}_{2}$ as wide band gap semiconductor. Furthermore, quasi-solid state electrolyte and PEDOT films on FTO glass as a counter electrode were used.

\section{Experimental sections}

Chemicals Ethanol $\left(\mathrm{CH}_{3} \mathrm{CH}_{3} \mathrm{OH}, 97 \%\right)$ was purchased from (Fluka). Fluorine doped tin oxide (FTO$1.5 \mathrm{~cm} \times 3 \mathrm{~cm}, 15 \Omega), \mathrm{TiO}_{2}(70 \%$ anatase and $30 \%$ rutile-P25-Degussa AG, Germany), EDOT, Tri-ton$100 \times$, polyvinyl pyrrolidone $(\mathrm{PVP})$, acetonitrile, $\left(\mathrm{C}_{2} \mathrm{H}_{5}\right)_{4}$ $\mathrm{NBF}_{4}$ and acetone all were purchased from Aldrich. Hydrochloric acid $(\mathrm{HCl}, 35 \%)$ was purchased from India.

\section{Preparation of natural dye sensitizers}

Enough amounts of the bracts of a shrub Bougainvillea spectabilis and the leaves of Euphorbia cotinifolia were collected in Bahir Dar city, Ethiopia. Before drying, the bracts and leaves were washed with tape water and then dried in laboratory for 6 weeks without light exposure. After drying, the bracts and leaves were crushed into fine powder using an electrical blender. Figure 1 shows the photographic picture of tree plants, the respective dried (a)

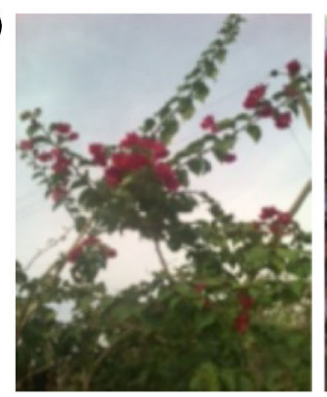

(b)

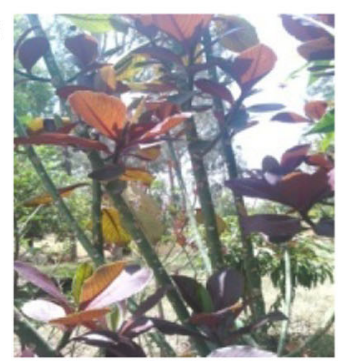

Plant
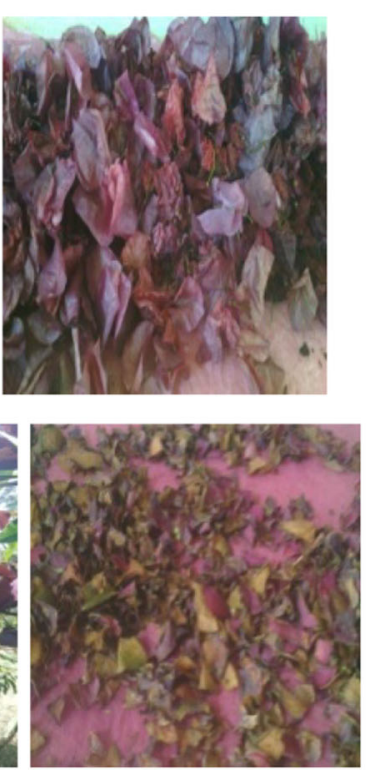

Dried leaves
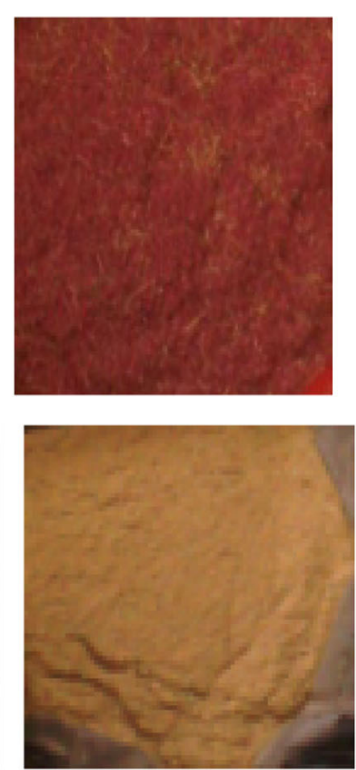

Powder
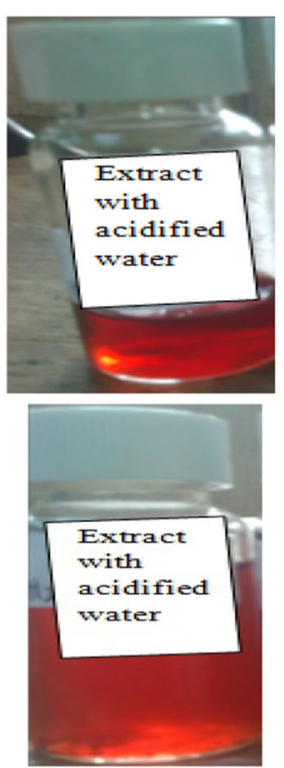

Extracted dye solutions

Fig. 1 Plant leaves used in this study a Bougainvillea spectabilis and $\mathbf{b}$ Euphorbia cotinifolia with their corresponding dried leaves, powders and extracted dye solutions 
bracts and leaves and the powder of the dried bracts of Bougainvillea spectabilis and leaves of Euphorbia cotinifolia. $2 \mathrm{~g}$ powder of the dried bracts of Bougainvillea spectabilis was separately extracted in $50 \mathrm{ml}$ ethanol and $50 \mathrm{ml}$ distilled water solvents that were acidified with $0.1 \mathrm{M} \mathrm{HCl}$ at room temperature.

Similarly, $2 \mathrm{~g}$ powder of the dried leaves of Euphorbia cotinifolia was separately extracted in $50 \mathrm{ml}$ of ethanol and $50 \mathrm{ml}$ of distilled water solvents that were acidified with $0.1 \mathrm{M} \mathrm{HCl}$ at room temperature. The glass containers were covered with aluminium foils to prevent damage from light exposure and were left for $24 \mathrm{~h}$ in dark conditions. The solids were filtered out first by decantation and then filtered by using glass filter. Finally, the dye was ready for optical characterization and to be used as sensitizers.

\section{Preparation of working electrode}

Fluorine doped tin oxide conductive glass sheets were first cleaned with distilled water, acetone and then ethanol for 10 min using ultrasonic bath at each step and then dried. The nanocrystalline $\mathrm{TiO}_{2}$ paste was prepared using commercial titanium dioxide powder. $3 \mathrm{~g}$ of commercial $\mathrm{TiO}_{2}$ powder was ground in a porcelain mortar with $1 \mathrm{ml}$ distilled water containing $0.1 \mathrm{ml}$ acetic acid to prevent reaggregation of the particles. Once the powder was dispersed by the high shear forces in the viscous paste, it was diluted by slow addition of $4 \mathrm{ml}$ distilled water under continued grinding in a porcelain mortar for half an hour. Finally, a nonionic surfactant $(0.05 \mathrm{~mL}$ Triton $\mathrm{X}-100)$, was added and the mixture was grinding for additional half an hour until a homogeneous paste was obtained. The surfactant was used to ease adhesion of $\mathrm{TiO}_{2}$ particles to FTO conductive glass substrate layer. Then, the conductive side of the FTO glass was covered on two parallel edges with adhesive tape to control the thickness of the $\mathrm{TiO}_{2}$ paste and to provide non-coated areas for electrical contact. The paste was spread on one of the free edges of the conducting glass using a glass rod-doctor blade method. After drying in air, the electrode was sintered for $30 \mathrm{~min}$ at $450{ }^{\circ} \mathrm{C}$ in a furnace (Carbolite Model ELF11/14 B). After cooling down, the electrode was immersed in the natural extracts for $24 \mathrm{~h}$. Finally, the electrode was withdrawn from the solution and rinsed with ethanol to remove the residues left on the $\mathrm{TiO}_{2}$ film and dried in air which would be used as photoelectrode.

\section{Preparation of counter electrode}

The counter electrode was prepared by coating the conductive side of FTO glass with poly (3,4-ethylenedioxythiophene) (PEDOT) film which was formed by electrochemical polymerization of 3,4 ethylenedioxythiophene (EDOT), in a three electrode system with one-compartment electrochemical cell. The electrochemical cell consisted of a precleaned FTO-coated glass working electrode, platinum foil counter electrode and quasi- $\mathrm{Ag} / \mathrm{AgCl}$ reference electrode. The solution used for the polymerization contained with $0.2 \mathrm{M}$ EDOT and $0.1 \mathrm{M}\left(\mathrm{C}_{2} \mathrm{H}_{5}\right)_{4} \mathrm{NBF}_{4}$ in acetonitrile. The monomer was used as received. The polymerization was carried out potentiostatically at $+1.8 \mathrm{~V}$ for $2 \mathrm{~s}$. At this potential, the electrode surface was covered with blue-doped PEDOT film. The cell was then rinsed with acetonitrile and dried in air. PEDOT improves the charge transfer between the FTO and the $\mathrm{I}_{3}{ }^{-} / \mathrm{I}^{-}$redox couple $[13,14]$. It is chosen as a counter electrode, because of less costly and can easily be prepared electrochemically to a desired transparency [15].

\section{Preparation of electrolyte}

The quasi-solid electrolyte, which had been used in this work, was prepared as follow: $0.9 \mathrm{M}$ of 3-ethyl-2- methyl Immidazolium iodide (EMIM-I) was added into acetonitrile under stirring to form a homogeneous liquid electrolyte. To obtain a better conductivity, $0.5 \mathrm{M}$ sodium iodide was dissolved in the above homogeneous liquid electrolyte, and then $0.12 \mathrm{M}$ iodine and $35 \%(\mathrm{~m} / \mathrm{m})$ of polyvinyl pyrrolidone were added. The resulting mixture was heated at $70-80{ }^{\circ} \mathrm{C}$ under vigorous stirring to dissolve the PVP polymer, followed by cooling down to room temperature to form a gel state electrolyte. Finally, the gel electrolyte was deposited in the form of thin film on top of the dye coated $\mathrm{TiO}_{2}$ electrode. The DSSC was completed by pressing gel electrolyte coated $\mathrm{TiO}_{2}$ electrode against PEDOT-coated FTO glass counter electrode.

Owing to its unique hybrid network structure, quasisolid-state electrolytes always possess, simultaneously, both the cohesive property of a solid and the diffusive transport property of a liquid [16]. Namely, quasi-solidstate electrolytes show better long-term stability than liquid electrolytes do and have the merits of liquid electrolytes including high ionic conductivity and excellent interfacial contact property $[17,18]$.

\section{Assembling of DSSC}

The prepared photoelectrode and counter electrode were placed one over the other face-to-face and hold with a clamps for performance evaluation as can be seen from the following schematic diagram, so that the electrolyte sandwiched between the titanium dioxide covered area of the working electrode and the PEDOT coated area of counterelectrode. The schematic representaion of the as prepared DSSC has been shown in Fig. 2. As seen in Fig. 2, the as prepared DSSC were attached to potentiostat equipment by means of cords and crocodile clips.

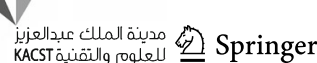




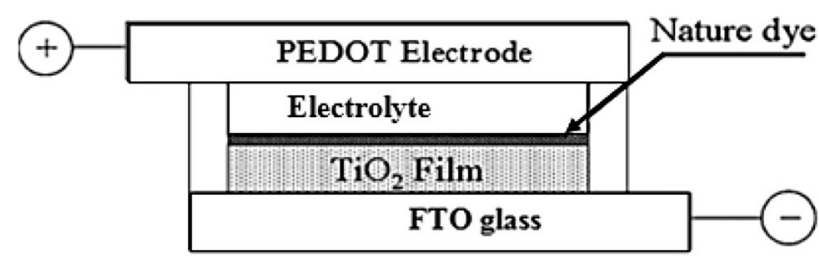

Fig. 2 A schematic representation of DSSCs

\section{Optical characterization and DSSC performance measurements}

The absorption spectra of the extracted pigments in acidified $(0.1 \mathrm{M} \mathrm{HCl})$ ethanol and distilled water solution separately were obtained using a UV-Vis spectrophotometer (PerkinElmer lambda 35). The absorption spectra analysis was carried out in the wavelengths ranging from 250 to $850 \mathrm{~nm}$. The photoelectrochemical measurements of the cells under illumination were performed using a computer controlled CHI630A Electrochemical Analyzer. A 250-W tungsten-halogen lamp regulated by an Oriel power supply (Model 68830) was used to illuminate the DSSC. The measured photocurrent was corrected for the spectral response of the lamp and the monochromator by normalization to the response of a calibrated silicon photodiode (Hamamatsu, Model S1336-8BK) whose sensitivity spectrum was known. No correction was made for the reflection from the surface of the sample. The illumination light intensity was measured in the position of the sample cell with Gigahertz-Optik X11 Optometer and the intensity of the incident light was $100 \mathrm{~mW} / \mathrm{cm}^{2}$.

\section{Results and discussion}

\section{Absorption of natural dyes}

The representative UV-Vis absorption spectra of the extracts of Bougainvillea spectabilis and Euphorbia cotinifolia have been investigated. Figures 3 and 4 show the UV-Vis absorption spectra of these extracts dissolved in acidified $(0.1 \mathrm{M} \mathrm{HCl})$ ethanol and distilled water separately. Figure 3 shows the absorption spectra of Bougainvillea spectabilis extracted by water and ethanol, acidified with $0.1 \mathrm{M} \mathrm{HCl}$. As can be seen from Fig. 3, in acidified distilled water extract, one peak was found around $545 \mathrm{~nm}$ maximum absorbance which can be associated to the presence of betalain, betalains in acidic environments have strong absorption in the $400-600 \mathrm{~nm}$ range due to the color combination of yellow-orange betaxanthins and redpink betacyanins [19, 20]. Differently, acidified ethanol extract of Bougainvillea spectabilis shows two absorption peaks around $655 \mathrm{~nm}$ (close to $660 \mathrm{~nm}$ ) and around

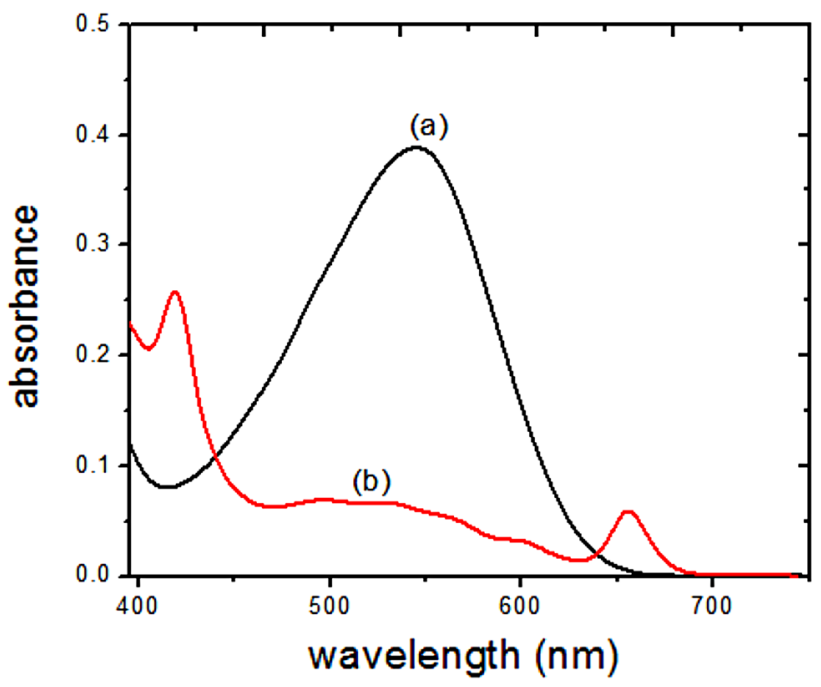

Fig. 3 UV-visible absorption spectrum of natural dye extracted from Bougainvillea spectabilis using acidified (with $0.1 \mathrm{M} \mathrm{HCl}$ ) $a$ distilled water and $b$ ethanol as extracting solvents

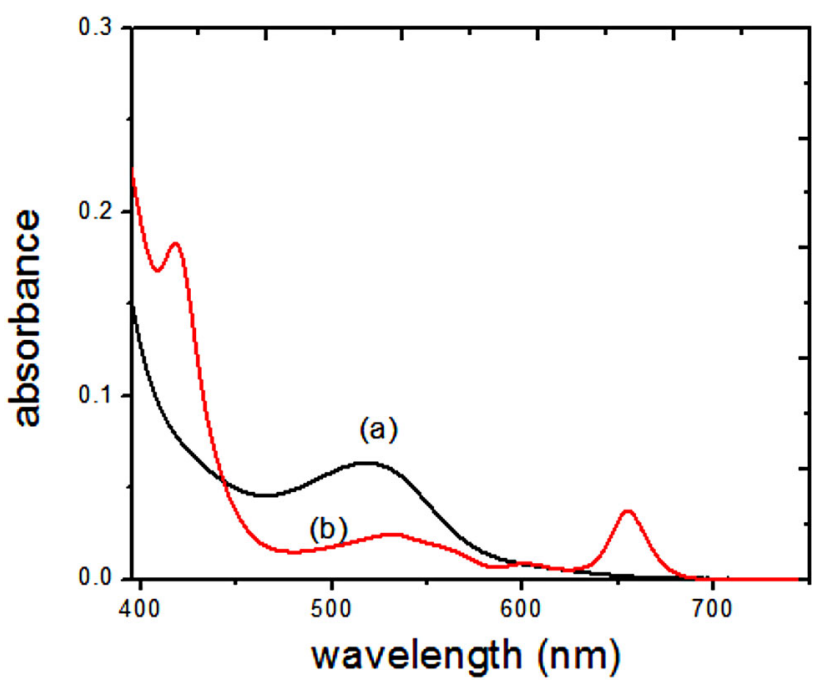

Fig. 4 UV-visible absorption spectrum of natural dye extracted from Euphorbia cotinifolia leaves using acidified (with $0.1 \mathrm{M} \mathrm{HCl}$ ) $a$ distilled water and $b$ ethanol as extracting solvents

$420 \mathrm{~nm}$ which might indicate the extract contains chlorophyll mixture which shows an absorption peak in between 400-500 $\mathrm{nm}$ and 600-700 $\mathrm{nm}$ [21] and also the extract has two small peaks between 476 and $545 \mathrm{~nm}$ which could be associated with the presence of betalains [22].

Figure 4 shows the absorption spectra of Euphorbia cotinifolia extracted by distilled water and ethanol, acidified with $0.1 \mathrm{M} \mathrm{HCl}$. As can be seen from Fig. 4, in acidified ethanol extract of Euphorbia cotinifolia, the extracted pigment had three absorption peaks at about 418 and $655 \mathrm{~nm}$ which show the characteristics absorption peak of chlorophyll mixture and the third absorption peak was at 
about $532 \mathrm{~nm}$ which might be associated with the presence of anthocyanin [9]. Differently, distilled water extract of Euphorbia cotinifolia had an absorption peak around $520 \mathrm{~nm}$ which might indicate the absorption of anthocyanins, a group of natural phenolics compounds. Anthocyanin is the core component of some natural dyes and is often found in the fruits, flowers, and leaves of plants [2]. Because anthocyanin shows color in the range of visible light from red to blue, it is predicted to become a highly efficient sensitizer for wide band gap semiconductors. In the acidified distilled water extracts, the concentration of dyes (betalain and anthocyanin) is expected to be higher than in acidified ethanolic extracts as can be seen from absorption spectra in Figs. 3 and 4, respectively, probably because of a higher solubility in water-polarity effect. But water extracts did not contain chlorophyll absorption since chlorophylls are relatively polar and are thus normally extracted with methanol, ethanol, acetone or other organic solvents miscible with water [20,23]. The acidity of the extract likely influences the solubility of various dyes, leading to extracts with different compositions.

Generally, the chlorophylls exhibit strong absorption in the blue and red regions of the solar spectrum [24]. However, they show poor absorption in the green region, which is consistent with our results.

\section{Photoelectrochemical properties}

Photovoltaic tests of the fabricated DSSCs using these natural dyes as photosensitizers were performed by measuring the $J-V$ characteristics of each cell under $100 \mathrm{~m} \mathrm{~W} /$ $\mathrm{cm}^{2}$ irradiation from a tungsten-halogen lamp. The performance of natural dyes as sensitizers in DSSCs was evaluated by short circuit current density $\left(J_{\mathrm{sc}}\right)$, open circuit voltage $\left(V_{\mathrm{oc}}\right)$, fill factor $(\mathrm{FF})$ and energy conversion efficiency $(\eta)$. Based on $J-V$ and $P-V$ results the fill factor (FF) and energy conversion efficiency $(\eta)$ were calculated using Eqs. (1) and (2).

$\eta=\frac{\mathrm{FF} \times J_{\mathrm{sc}} \times V_{\mathrm{oc}}}{P_{\text {in }}} \times 100 \%$

where $P_{\text {in }}$ is the power of incident light, $V_{\mathrm{oc}}$ is open circuit voltage; $J_{\mathrm{sc}}$ is short circuit current density

$F F=\frac{J_{\mathrm{m}} \times V_{\mathrm{m}}}{J_{\mathrm{sc}} \times V_{\mathrm{oc}}}$

where $J_{\mathrm{m}}$ and $V_{\mathrm{m}}$ are the photocurrent density and photovoltage for maximum power output $P_{\mathrm{m}}$.

Figures 5 and 6 show the typical $J-V$ curves of the as prepared DSSCs using the sensitizers extracted from Bougainvillea spectabilis and Euphorbia cotinifolia. All the photoelectrochemical parameters of the DSSCs assembled with these natural dyes are listed in Table 1. As

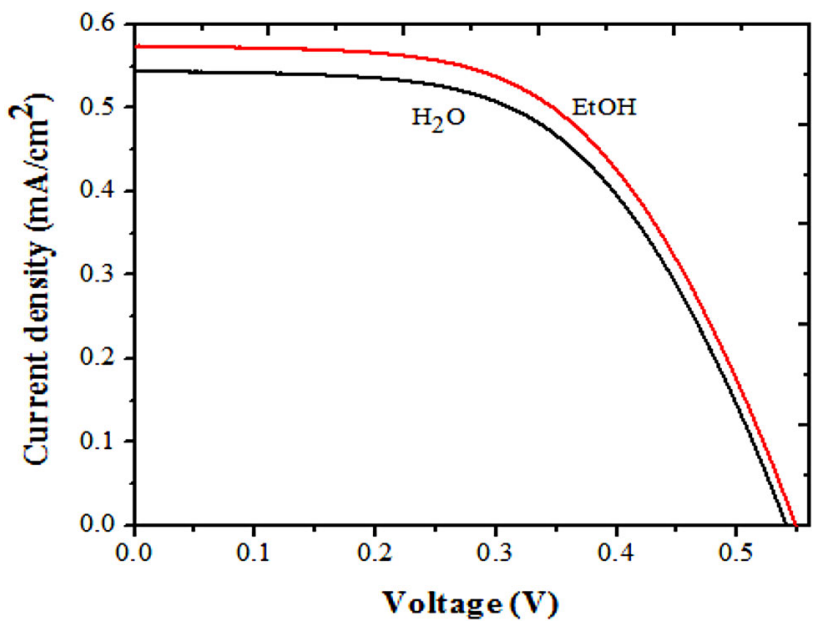

Fig. $5 J-V$ characteristic curves of Bougainvillea spectabilis bracts using acidified ethanol $(\mathrm{EtOH})$ and distilled water $\left(\mathrm{H}_{2} \mathrm{O}\right)$ as extracting solvents

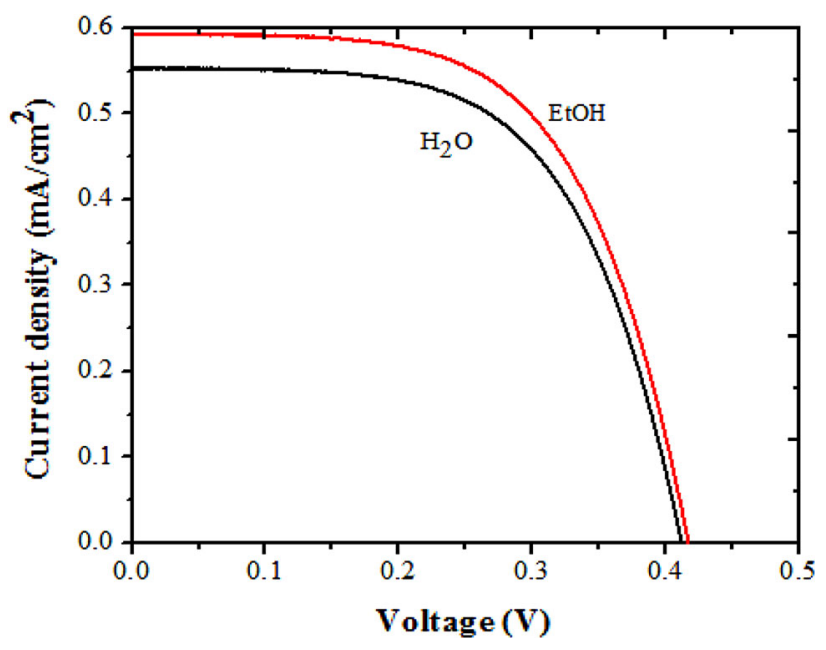

Fig. $6 J-V$ characteristic curves of Euphorbia cotinifolia leaves using acidified ethanol $(\mathrm{EtOH})$ and distilled water $\left(\mathrm{H}_{2} \mathrm{O}\right)$ as extracting solvent

depicted in Table 1, the fill factor of the fabricated DSSCs ranges between 0.552 to 0.603 . The $V_{\mathrm{oc}}$ changes from 0.411 to $0.549 \mathrm{~V}$, and the $J_{\mathrm{sc}}$ varies from 0.541 to $0.592 \mathrm{~m}$ $\mathrm{A} / \mathrm{cm}^{2}$. Specifically, a high $V_{\mathrm{oc}}=0.549 \mathrm{~V}$ and $J_{\mathrm{sc}}=0.592 \mathrm{~mA} / \mathrm{cm}^{2}$ were obtained from the DSSCs sensitized by the dyes of Bougainvillea spectabilis and Euphorbia cotinifolia, respectively, that were extracted by acidified ethanol. These data are significantly higher than those of the DSSCs sensitized by other natural dyes in this work.

The highest output power and energy conversion efficiency were obtained for the DSSC sensitized with acidified ethanolic extract of Bougainvillea spectabilis where the efficiency of the cell reached $0.175 \%$. This might be 
Table 1 The photoelectrochemical parameters of the as prepared DSSCs

\begin{tabular}{|c|c|c|c|c|c|c|c|c|c|c|}
\hline Plant & Solvent & $V_{\mathrm{oc}}(\mathrm{V})$ & $\begin{array}{l}J_{\mathrm{sc}} \\
\left(\mathrm{mA} / \mathrm{cm}^{2}\right)\end{array}$ & $V_{\max }(\mathrm{V})$ & $\begin{array}{l}J_{\max } \\
\left(\mathrm{mA} / \mathrm{cm}^{2}\right)\end{array}$ & $\begin{array}{l}P_{\text {in }}(\mathrm{mW} / \\
\left.\mathrm{cm}^{2}\right)\end{array}$ & $\mathrm{FF}$ & $\begin{array}{l}P_{\max } \\
\left(\mathrm{mW} / \mathrm{cm}^{2}\right)\end{array}$ & $\eta(\%)$ & Remarks \\
\hline \multirow[t]{2}{*}{ Bougainvillea spectabilis } & Water & 0.541 & 0.545 & 0.361 & 0.454 & 100 & 0.552 & 0.164 & 0.164 & Current work \\
\hline & Ethanol & 0.549 & 0.574 & 0.371 & 0.471 & 100 & 0.555 & 0.175 & 0.175 & \\
\hline \multirow[t]{2}{*}{ Euphorbia cotinifolia } & Water & 0.411 & 0.553 & 0.295 & 0.464 & 100 & 0.602 & 0.137 & 0.137 & \\
\hline & Ethanol & 0.417 & 0.592 & 0.299 & 0.498 & 100 & 0.603 & 0.149 & 0.149 & \\
\hline Commercial carrot & Ethanol & 0.010 & 35.4 & 75.4 & 29.3 & & 0.61 & & 0.015 & {$[30]$} \\
\hline Hibiscus flower & Ethanol & 0.268 & 0.96 & & & & 0.43 & & 0.11 & {$[31]$} \\
\hline Lawsonia inermis & Ethanol & 1.60 & 0.91 & & & & 0.96 & & 1.39 & [32] \\
\hline
\end{tabular}

associated with the combination presence of chlorophyll and betalain pigments in the extract to absorb photons-a synergistic effect of two sensitizing pigments. Although there may not be a single pigment that can act as a highly efficient sensitizer, it is possible that a combination of pigments could provide the absorbance necessary to increase the efficiency of a DSSC. In fact, some research has demonstrated a synergistic effect of two sensitizing pigments, meaning the absorption spectra of two pigments combined to increase light absorption and increase the incident photon to current conversion efficiency of the solar cell $[25,26]$. Chlorophyll plays an important role in plant photosynthesis; the DSSCs using chlorophyll derivatives as sensitizers obtained a relatively high conversion efficiency $[15,16]$. This is because there are available bonds between the dye and $\mathrm{TiO} 2$ molecules through which electrons can transport from the excited dye molecules to the $\mathrm{TiO} 2$ film [17]. This result indicates that the interaction between the sensitizer and the $\mathrm{TiO} 2$ film is significant in enhancing the power conversion efficiency of DSSCs. The DSSC output power was calculated as $P=J \times V$ using the $J-V$ data. The maximum power $\left(P_{\max }\right)$ of the DSSCs for each cell is then calculated. The current $\left(I_{\max }\right)$ and the voltage $\left(V_{\max }\right)$ corresponding to the maximum power point are then obtained. Generally, the natural dyes employed as sensitizers in solar cell deliver very low efficiencies when compared to synthetic organic and inorganic dyes, due to the absence of specific functional attachment groups and low absorption in the visible region of the solar spectrum [27, 28]. The conversion efficiencies of the as prepared DSSCs in this study were better as compared to some DSSC values reported as shown in Table 1. But, the obtained conversion efficiencies were lower than those reported [32] for natural dye based DSSCs may be due to several reasons. Of them one potential reason for the low efficiencies is due to the inconsistency of the $\mathrm{TiO}_{2}$ film thickness in the layer [29]. The uniformity of the $\mathrm{TiO}_{2}$ film thickness affects the conversion efficiency of the solar cell. If the film thickness is not uniform, charge recombination can occur and the energy conversion efficiency of the DSSC will be reduced. Despite the low efficiencies, the as prepared DSSCs exhibit the applicability of Bougainvillea spectabilis and Euphorbia cotinifolia dyes for photovoltaic energy conversion.

\section{Conclusion}

The Bougainvillea spectabilis and Euphorbia cotinifolia extracts were used as low-cost sensitizers for commercial $\mathrm{TiO}_{2}$ nanoparticles photoanode based dye sensitized solar cell. The UV-Vis absorbance measurement of the Bougainvillea spectabilis and Euphorbia cotinifolia extracts in acidified distilled water and ethanol as a solvent were carried out and the extracts had absorption peaks in the visible light regions due to the presence of plant pigments such as chlorophyll and betalain in Bougainvillea spectabilis and chlorophyll and anthocyanin in Euphorbia cotinifolia. The photovoltaic performance of the extracts as sensitizers for the constructed DSSCs was evaluated under simulated solar light irradiation. The solar cell sensitized with these extracts delivered short-circuit photocurrent densities $\left(J_{\mathrm{sc}}\right)$ ranging from 0.545 to $0.592 \mathrm{~mA} / \mathrm{cm}^{2}$, open circuit voltages $\left(V_{\mathrm{oc}}\right)$ varied from 0.411 to $0.549 \mathrm{~V}$ and the fill factors varied from 0.552 to 0.603 . The highest open circuit voltage $\left(V_{\mathrm{oc}}=0.549 \mathrm{~V}\right)$ and short circuit current density $\left(J_{\mathrm{sc}}=0.592 \mathrm{~mA} / \mathrm{cm}^{2}\right)$ were obtained from the DSSCs sensitized by the acidified ethanol extracts of Bougainvillea spectabilis bracts and Euphorbia cotinifolia leaves, respectively. The highest power conversation efficiency $(\eta)$ of the prepared DSSC was $0.175 \%$.

The overall results of the study suggest that the exploitation of Bougainvillea spectabilis and Euphorbia cotinifolia pigments as natural sensitizers along with the use of quasi-solid electrolyte and PEDOT coated FTO counter electrodes could be a possible alternative for the production of low-cost and environment friendly DSSCs.

Acknowledgments The authors gratefully acknowledge the financial support provided by Bahir Dar University, Energy Research center for the study undertaking. 
Open Access This article is distributed under the terms of the Creative Commons Attribution 4.0 International License (http:// creativecommons.org/licenses/by/4.0/), which permits unrestricted use, distribution, and reproduction in any medium, provided you give appropriate credit to the original author(s) and the source, provide a link to the Creative Commons license, and indicate if changes were made.

\section{References}

1. Godibo, D.J., Anshebo, S.T., Anshebo, T.Y.: Dye sensitized solar cells using natural pigments from five plants and quasi-solid state electrolyte. J. Braz. Chem. Soc. 26(1), 92-101 (2015)

2. Wongcharee, K., Meeyoo, V., Chavadej, S.: Dye-sensitized solar cell using natural dyes extracted from rosella and blue pea flowers. Sol. Energy Mater. Sol. Cells 91(7), 566-571 (2007)

3. Grätzel, M.: Dye-sensitized solar cells. J. Photochem. Photobiol. C 4, 145 (2003)

4. Karuppuchamy, S., Jeong, J.M., Amalnerkar, D.P., Minoura, H.: Photoinduced hydrophilicity of titanium dioxide thin films prepared by cathodic electrodeposition. Vacuum 80, 494-498 (2006)

5. Tennakone, K., Kumara, G.R.R.R.A., Kumarasinghe, A.R., Sirimanne, P.M., Wijayantha, K.G.U.: Efficient photosensitization of nanocrystalline $\mathrm{TiO}_{2}$ films by tannins and related phenolic substances. J. Photochem. Photobiol. A 94, 217-220 (1996)

6. Mounir Alhamed, A.S.I., Wael Doubal, A.: Studying of natural dyes properties as photo-sensitizer for dye sensitized solar cells (DSSC). J. Electron Devices 16, 1370-1383 (2012)

7. Hao, S., Wu, J., Huang, Y., Lin, J.: Natural dyes as photosensitizers for dye-sensitized solar cell. Sol. Energy 80, 209-214 (2006)

8. Cherepy, N.J., Smestad, G.P., Grätzel, M., Zhang, J.Z.: Ultrafast electron injection: implications for a photoelectrochemical cell utilizing an anthocyanin dye-sensitized $\mathrm{TiO}_{2}$ nanocrystalline electrode. J. Phys. Chem. B 101, 9342 (1997)

9. Kevin Gould, K.D., Winefield, C.: Anthocyanins Biosynthesis, Functions, and Applications. Springer Science, USA (2009)

10. AntonioLuque, S.H.: Handbook of Photovoltaic Science and Engineering, 1st edn. John Wiley \& Sons Ltd Publishers, UK (2003)

11. Nwanya, A.C., Ugwuoke, P.E., Ejikeme, P.M., Oparaku, O.U., Ezema, F.I.: Jathropha curcas and citrus aurantium leaves dye extract for use in dye sensitized solar cell with $\mathrm{TiO}_{2}$ films. Int. J. Electrochem. Sci. 7, 11219-11235 (2012)

12. Li, Y., Ku, S.-H., Chen, S.-M., Ali, M.A., AlHemaid, F.M.A.: Photoelectrochemistry for red cabbage extract as natural dye to develop a dye-sensitized solar cells. Int. J. Electrochem. Sci. 8, 1237-1245 (2013)

13. Sergawie, A.: A PhD thesis on solar energy conversion based on organic and organic/inorganic hybrid solar cells (2007). http:// hdl.handle.net/123456789/675

14. Granström, M., Petritsch, K., Arias, A.C., Lux, A., Andersson, M.R., Friend, R.H.: Laminated fabrication of polymeric photovoltaic diodes. Nature 395, 257-260 (1998)

15. Yohannes, T., Inganäs, O.: Photoelectrochemical studies of the junction between poly[3-(4-octylphenyl)thiophene] and a redox polymer electrolyte. Sol. Energy Mater. Sol. Cells 51, 193 (1998)
16. Wu, J., Lan, Z., Hao, S., Li, P., Lin, J., Huang, M., Fang, L., Huang, Y.: Progress on the electrolytes for dye-sensitized solar cells. Pure Appl. Chem. 80(11), 2241-2258 (2008)

17. Murphy, S.B.R., Stepto, R.F.T. (eds.): Polymer networks-principles of their formation, structure and properties. Blackie Academic, London (1998)

18. Nogueira, A.F., Longo, C., De Paoli, M.A.: Coord. Chem. Rev. 248, 1455 (2004)

19. Hemmatzadeh, R., Mohammadi, A.: Improving optical absorptivity of natural dyes for fabrication of efficient dye-sensitized solar cells. J. Theor. Appl. Phys. 7, 1-7 (2013)

20. Quin, C., Clark, A.E.: DFT characterization of the optical and redox properties of natural pigments relevant to dye-sensitized solar cells. Chem. Phys. Lett. 438, 26-30 (2007)

21. Hernández-Martínez, A.R., Estevez, M., Vargas, S., Quintanilla, F., Rodríguez, R.: Natural pigment-based dye-sensitized solar cells. J. Appl. Res. Technol. 10(1), 38-47 (2012)

22. Al-Alwani, M.A.M., Mohamad, A.B., Kadhum, A.A.H., Ludin, N.A.: Effect of solvents on the extraction of natural pigments and adsorption onto $\mathrm{TiO} 2$ for dye-sensitized solar cell applications. Mol. Biomol. Spectrosc. 138, 130-137 (2015)

23. Minguez-Mosquera, M.I., Gandul-Rojas, B., Gallardo-Guerrero, L., Jaren-Galan, M.: Chlorophylls. In: Hurst, W.J. (ed.) Methods of Analysis for Functional Foods and Nutraceuticals, pp. 159-218. CRC Press, Boca Raton (2002)

24. Davies, K.M. (ed.): Plant Pigments and their Manipulation. Annual Plant Reviews, vol. 14. Wiley (2009)

25. Liu, B.Z., Zhao, X.P., Luo, W.: The synergistic effect of two photosynthetic pigments in dye-sensitized mesoporous $\mathrm{TiO}_{2}$ solar cells. Dyes Pigm. 76, 327-331 (2008)

26. Kumara, G.R.A., Kaneko, S., Okuya, M., Onwona-Agyeman, B., Konno, A., Tenakone, K.: Shiso leaf pigments for dye-sensitized solid-state solar cell. Sol. Energy Mater. Sol. Cells. 90, 1220-1226 (2006)

27. Anand, M., Suresh, S.: Marine seaweed Sargassum wightii extract as a low-cost sensitizer for $\mathrm{ZnO}$ photoanode based dyesensitized solar cell. Adv. Nat. Sci. Nanosci. Nanotechnol. 6, 035008 (2015). (8 pp)

28. Hagfeldt, A., Boschloo, G., Sun, L., Kloo, L., Pettersson, H.: Dye-sensitized solar cells. Chem. Rev. 110, 6595 (2010)

29. Hamadanian, M., et al.: The effect of the thickness of nanoporous $\mathrm{TiO}_{2}$ film on the performance of nanocrystalline dye-sensitized solar cell. 5th Symposium on Advances in Science and Technology, Mashad, Iran (2011)

30. Win, S.Y., Win, T.T., Maung, Y.M., Soe, K.K.K., Kyaw, T.T., Tan, C.K., Rajalingam, S., Oo, Z.: Synthesis of nanoparticalbased binary oxide electrode $\mathrm{TiO}_{2}-\mathrm{ZrO}_{2}$ with carrot-derived natural dye extract for dye sensitized solar cell (DSSC) application. Pertanika J. Sci. Technol. 23(1), 119-125 (2015)

31. Mansa, R.F., Govindasamy, G., Farm, Y.Y., Bakar, H.A., Dayou, J., Sipaut, C.S.: Hibiscus flower extract as a natural dye sensitiser for a dye-sensitised solar cell. J. Phys. Sci. 25(2), 85-96 (2014)

32. Sakthivel, S., Baskaran, V., Mahenthiran, S.: Dye sensitized solar cell properties and fabrication using Lawsonia inermis. J. Chem. Chem. Sci. 5(2), 85-92 (2015) 